\title{
The African honeybee in Peru: an insect invader and its impact on beekeeping
}

\author{
Robert B. Kent \\ Department of Geography, University of Akron, Akron, OH 44325, USA
}

\begin{abstract}
In 1956 scientists introduced a honeybee race, Apis mellifera scutellata, from East Africa into Brazil. This honeybee subsequently escaped from captivity, hybridized with existing honeybee populations and has diffused over much of South America. This paper examines the impact of this diffusion in one South American country, Peru, comparing beekeeping practice and management techniques in the region infested with the aggressive hybrid and in the region free of the hybrid. The study reveals consistent differences between the two regions in almost all criteria examined. Beekeepers in the African region are characterized by the use of more modern equipment, better management techniques, and more successful and commercially orientated beekeeping operations. While the presence of the African honeybee has been bothersome to those Peruvian beekeepers with it in their apiaries, the bee has proved to be neither as damaging nor as disruptive as is frequently suggested. Indeed, Peruvian beekeepers have adapted to the bee's presence with comparative ease and with no organized assistance from public or private agencies. The results of this study suggest that the impact of the African bee's arrival in central and northern Mexico and in the southern United States will not be nearly as disruptive and severe as many people believe.
\end{abstract}

\section{Introduction}

Biological invasions of exotic plants, animals and pathogens represent potentially severe disruptions of ecological relationships in natural, agricultural and human systems (Elton 1958; Mooney and Drake 1987). Humans have frequently been responsible for these introductions, both intentionally and unintentionally. The exploration and colonization of many areas of the world by Europeans during the last several hundred years greatly accelerated this process (Crosby 1986). As international trade and travel have increased during the present century opportunities for the introduction of biological exotics have increased (Calkins 1983: 352). The case of immigrant insects and mites in the United States is illustrative: approximately 300 species of exotics were present in 1900, whereas now there are nearly 1500 (Sailer 1983: 23). Although comparatively few insect or other invaders become serious pests, it is cstimated that in the US alonc the losses in agriculture and forestry due to biological pest invaders exceed billions of dollars annually (Pimental 1986: 160).

Insects are frequent biological invaders. They may be inadvertently introduced into new environments with relative ease due to their small size and in some cases their ability to remain dormant for extended periods. They have also been intentionally introduced into new environments and it has been suggested that the 'most unqualified mistakes in species introductions' have been those involving insects (Sharples 1983: 47). Whether intentional or not, the introduction of many insect species can have dire ecological and economic consequences. In North America the 
gypsy moth, the codling moth, the boll weevil and the Mediterranean fruit fly clearly demonstrate the potential damage that can be caused by insect invaders (Gerardi and Grimm 1979; Horsfall 1983: 8-12).

One of the most dramatic incidents of the introduction of an insect invader in the present century has been the arrival from East Africa of the African honeybee, Apis mellifera scutellata, in Brazil, in the mid-1950s. The bee escaped from an experimental apiary, hybridized with other honeybee populations in Brazil, and diffused over most of South America, through Central America and into the extreme south of Mexico between 1957 and 1987. During this period it hybridized with other exotic honeybee races which had been introduced into the New World at various times since the 1800s (Kent 1988). The African hybrid's purported aggressiveness and danger to beekeepers and the public at large has created considerable concern in Mexico and the US as the bee has diffused north (McDowell 1984; Taylor 1985). Consequently, the two governments are presently attempting to establish a biological barrier across the Isthmus of Tehuantepec (Moffett et al. 1987; Rinderer et al. 1987; Fierro et al. 1988; Tew et al. 1988).

The disruptive consequences of the arrival of this hybrid on beekeepers, the beekeeping industry and the public in countries into which it has diffused, have been widely reported. Frequently these accounts are exaggerated or simply untrue (Nunamaker 1979). In the academic and trade literature the focus of research has been on the biological characteristics of the hybrid and general discussions of the bee's impact. Yet detailed studies documenting the impact of the hybrid bee are rare. Consequently, public policy decisions regarding measures to halt or retard the advance of this hybrid and decisions on how to ameliorate the effects of the bee should it reach the southern US are being taken without adequate data. This is surprising, given the attention the $\Lambda$ frican hybrid has received from bee biologists and other scientists and the oft-repeated statements of ecologists, who suggest that the best methods of preparing for a biological invader are detailed field study and the collection of cmpirical data about the invader before it invades (Calkins 1983: 333; Lattin and Oman 1983: 97; Simberloff 1986: 24). For example, Roughgarden (1986: 179 ), in his review of modelling the invasion process, suggests that it is worth stressing that the best prediction is provided by empirical precedent, and not by a model at all'.

The purpose of this paper is to evaluate the impact of the African honeybee in Peru, onte of the two countries in South America which have regions free of the African hybrid as well as regions where the hybrid has been established for at least ten years. The paper compares beekeeping practices and production between areas where the African honeybee has been present for many years, and locations which at the time of the study (the early and mid-1980s) were free from the influence of the hybrid. The conclusions contribute to the development of sound public policy decisions by the appropriate agencies in Mexico and the US on how to address the problems created by the hybrid when it arrives.

The terminology used to describe this hybrid honeybee has varied. Some researchers in the early 1970s referred to it as the Brazilian honeybee (Michener 1973, 1975). Brazilian scientists objected to this term, suggesting a more appropriate term to be the 'Africanized honeybee' (Gonçalves 1974), and this term has been widely used. More recent research has clearly established that the hybrid is so similar to the African honeybee, Apis mellifera scutellata, originally introduced in Brazil, that it cannot be considered a distinct race (Winston 1987; Camazine and Morse 1988). In the light of this research and in the interest of simplicity, the hybrid honeybee will be referred to in this paper as the African honeybee or the African hybrid. 


\section{Arrival, diffusion and distribution}

The presence of the African honeybee in Peru dates from the early 1970s. The hybrid first appeared east of the Andes in the Amazon Basin in 1974 in the Department of Ucavali (Figs 1 and 2) (Taylor 1977: 20). Later reports placed the bee at higher elevations in the foothills of the east-facing slopes of the Andes within two to three years (Dávila et al. 1980). Beekeepers in the Departments of Pasco and Junin began to experience the effects of the hybrid in late 1976 and 1977 (Alata Condor 1976; Frey 1982). At about the same time, the hybrid appeared in the vicinity of Tarapoto (Murakami 1982), in the Department of Junin (Kaufman 1981), in Quillabamba (Spivak 1981), in the Department of Cajamarca, and in other locations in the lowlands and the Andean foothills (Daly 1981). Beekeepers in these areas cited frequent swarms of feral honeybees and increased numbers of feral colonies as initial indicators of the presence of the hybrid. Later they noticed increased swarming in their apiaries and greater aggressiveness by their bees. Between 1974 and 1978 the hybrid established itself throughout the entire region below approximately $1500 \mathrm{~m}$ on the eastern side of the Andes (see Fig. 1).

Despite close geographical proximity, the hybrid has not successfully established itself at elevations above $1500 \mathrm{~m}$ in the Andes. In the central region of the Peruvian Andes one beekeeper has practised migratory beekeeping for some time. For five years during the late 1970s and early 1980s he moved his hives between the Amazonian lowlands and the Andes to take advantage of complementary seasonal honey flows in each region (Caballero 1981). While the bees in his apiary demonstrate predominantly African characteristics, especially strong nest defence (aggressiveness), other apiaries nearby did not demonstrate African characteristics even after ycars of exposure to these bees (Pizarro 1982). In the intermontanc valleys at lower elevations, feral swarms of African bees periodically appear, as they have in the area of Cajamarca, in northern Peru, but their permanent establishment in the intermontane valleys of the Andes does not appear to have occurred. This is probably due to consistently cooler temperatures and occasional freezes common to the highlands. Nevertheless, recent research in Colombia suggests that the African hybrid may be capable of surviving at much higher altitudes than has generally been believed possible (Villa 1987).

The coastal regions of Peru remained free of the African hybrid for a number of years because of the environmental barrier the Andes presented to its diffusion. However, in the late 1970s the hybrid appeared on the north coast in the Departments of Tumbes and Piura (Dávila et al. 1980: 125). It diffused southwards and by late 1985 had reached about half-way down the coastal margin towards Lima. The bee spread north into Ecuador, too, and by late 1981 was established throughout most of the southern coastal region (Harper 1982: 7). Now it is the dominant honeybee race throughout coastal Ecuador.

The arrival of the African hybrid on the north coast of Peru in 1978 or 1979 can be traced, with a fair degree of confidence, to the activities of two commercial beekeepers. In 1978 they purchased 300 colonies on the eastern side of the Andes in an area infested with the African hybrid (Lizarraga 1981). These hives were transported to apiary sites in the coastal departments of Tumbes and Piura (see Figs 1 and 2). The beekeepers reported that upon arrival in the north they reviewed all the colonies and requeened those demonstrating aggressive characteristics with more docile Italian bees imported from the USA. This, they assert, effectively eliminated the possibility that they could have been responsible for the introduction of the African hybrid to the coastal areas. However, other commercial and hobby beekeepers in the area 


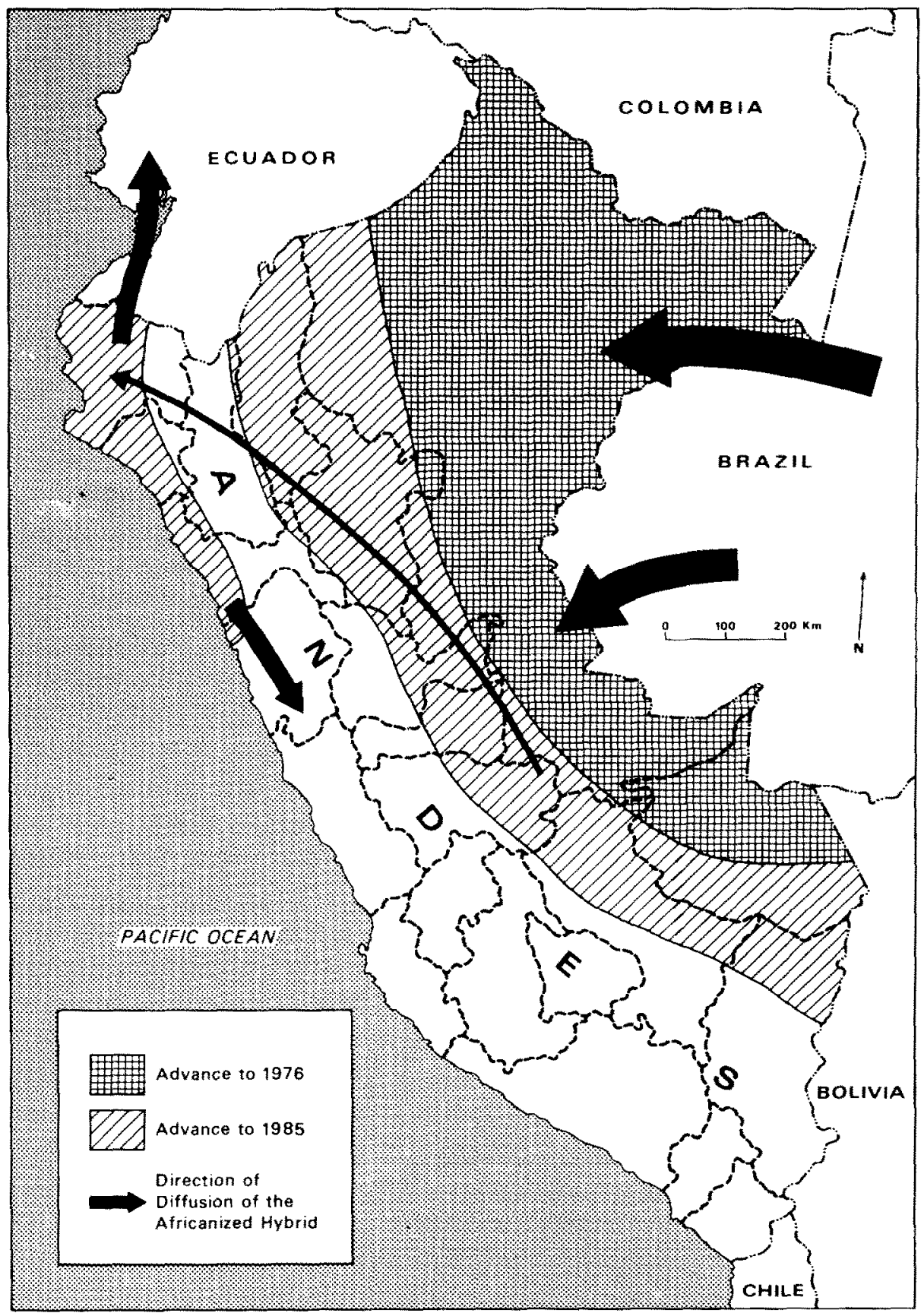

Figure 1. Diffusion of the African honeybee in Peru. 


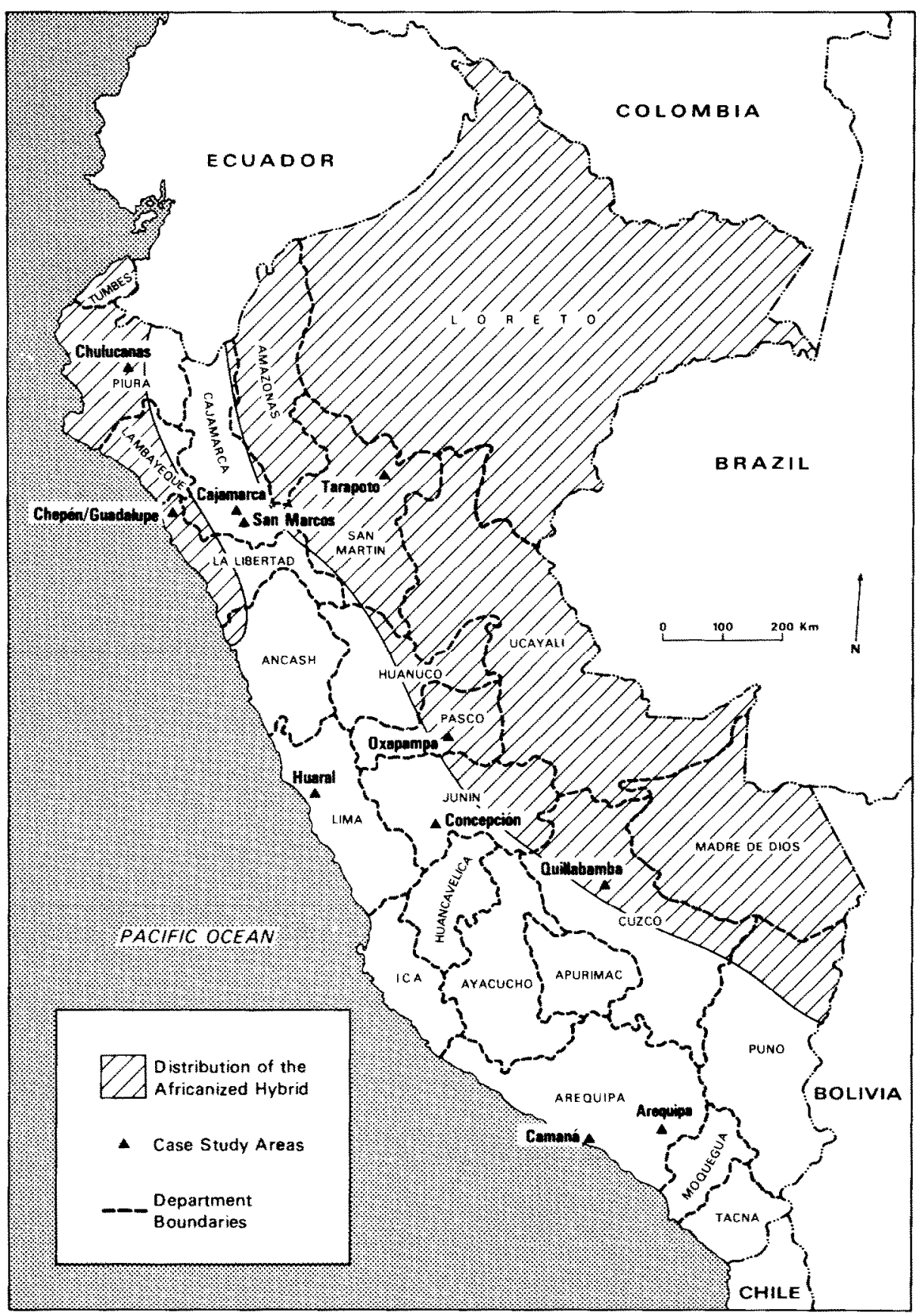

Figure 2. Distribution of the African honeybee in Peru and the location of case study sites. 
around Chulucanas, where the beekeepers established apiaries with the transferred colonies, remember increased aggressiveness and swarming by bees in their apiaries shortly after the arrival of these colonies (Ojeda 1981). Regardless of the origin or responsibility for the introduction of the African hybrid on the north coast, the bee is now well established there and in Ecuador. If the hybrid demonstrates the same diffusion characteristics there that it has in the rest of South America, it will spread south along the coast to Lima and the irrigated valleys on the southern coast within the next few years and then diffuse into the oases of northern Chile. The African hybrid's ability to abscond or swarm as far as $100 \mathrm{~km}$ from the original hive location allows it to diffuse relatively easily down South America's west coast desert (Seeley 1985). It is unlikely, however, that it will diffuse much farther south than Valpariaso or Santiago (at about $33^{\circ} \mathrm{S}$ ) because the cooler climates south of that latitude would make it difficult for it to survive.

\section{Methodology}

The analysis of the African honeybee's impact in Peru, and beekeepers' responses to it, is accomplished by a comparison of beekeeping practice and production between regions free of the hybrid and those infested by it. The lack of any significant historical data on Peruvian beekeeping at either the national, regional or local level precluded the possibility of attempting to establish change within a region or case study site before and after the arrival of the hybrid. The distribution of the hybrid at the time of this fieldwork (1981 82) was determined through interviews with the leading beekeepers in the country and a review of the published material on the subject available in Peru. Besides selecting case study sites in areas free of the hybrid and those invaded by it, sitcs were sought where beekecping had been practised for a considerable number of years so that stable conditions representative of a number of years could be obtained. Furthermore, sites were selected throughout the country to ensure that local variations in beekeeping conditions and management practices would not unduly bias the results of the study. Finally, the selection of sites was constrained by two other factors. First, they had to be areas that could be readily reached by transportation available to the general public (buses, pick-up trucks or cargo trucks), since private transportation was not available in the field. Secondly, the case study sites had to be small towns or cities where food and lodging were available. Using these criteria, five case studies were conducted in regions where the hybrid was present-Chulucanas, Chepén/Guadalupe, Tarapoto, Oxapampa and Quillabamba, and six case studies outside the region affected by the hybridCajamarca, San Marcos, Huaral, Camaná, Concepción and Arequipa (see Fig. 2).

In other South American countries where the hybrid bee has been present for many years, a considerable body of literature has accumulated identifying a range of variables related to beekeeping which are reported to be affected by the hybrid's presence. These fall into four major classes: management practice, honey production, apiary characteristics, and the economic status of beekeepers. Most beekeepers find management requirements more demanding and capital intensive with the African bee. The need for more and better protective clothing and equipmentgloves, masks, overalls, boots, and smokers-is one of the chief reasons (Kempff Mercado 1973: 125; ' Iaylor and Williamson 19/5: 93; Wiese 1977: 168; Sommer 1979: 78). The tendency for the hybrid to swarm and abscond more frequently also necessitates more intensive management. Typically, it has been suggested that the hybrid is a more prolific honey producer and that after an initial period of adjustment, when yields may decline, honey yields tend to increase notably (Cornejo 1971: 
262-3; Taylor and Williamson 1975: 93; Gonçalves 1978: 475; Sommer 1979: 77; Stort and Gonçalves 1979: 35). The aggressive hive defence demonstrated by the African bee is said to require changes in the location of apiaries. Before the arrival of the hybrid, beekeepers in South American generally located their hives near dwellings and farmsteads so they would be accessible and to reduce the problems of theft. Due to the hybrid's aggressive hive defence, this proximity is troublesome, and beekeepers and apiculturalists have advised that hives with hybrid bees should be located far $(200-500 \mathrm{~m})$ from homes, barns, animals, walkways and roads (Kempff Mercado 1973: 124; Taylor and Williamson 1975: 93; Sommer 1979: 77; Stearman 1981: 31). Finally, the arrival of the African bee appears to have a negative impact on the ability of many to continue keeping bees. Part-time and hobby beekeepers are most seriously affected because frequently they do not have the means to make the necessary investment in better equipment or to locate or to move apiaries to isolated sites (Wiese 1977: 166-7; Gonçalves 1978: 479; Presada 1981: 630). Consequently, these individuals may abandon beekeeping, while commercial beekeepers with greater financial resources and technical knowledge are more likely to continue keeping bees.

A questionnaire was designed to assess beekeeping conditions in each study area. It sought information on management practices, honey production, apiary characteristics, economic status, and beekeeper education. It identified specific variables, as reported from other South American countries affected by the hybrid, which are directly influenced by the hybrid bee's presence in beekeepers' apiaries, and from an earlier survey conducted in Brazil by a committee of the US National Academy of Sciences (Committee on the African Honeybee 1972). The questionnaire also queried beekeepers on perceived problems, changes in the behaviour of their bees over the past few years, knowledge of the African honeybee's presence in Peru, and its presence or absence in their locality. If they believed the hybrid to be present, additional information was gathered on changes in management techniques, production, apiary location, and changes in apiary size since its arrival. A total of 112 beekeepers were surveyed in the 11 study areas.

Besides the questionnaire, an apiary observation sheet was used to collect data on apiary size, location, hive type, condition, and local vegetation. The data collected included information on the distance of the apiary from human habitation and livestock pens and reports of stinging incidents of neighbours and livestock. One hundred and thirty-five apiaries were visited during the course of the fieldwork.

Because no government data are available on the number of beekeepers or apiaries at a local or even provincial level, a simple survey technique was employed in each case study area to survey beekeepers and apiary conditions. Using maps of the area surrounding each case study site, a circular area with a $3-\mathrm{km}$ radius was established. The principal roads and trails in each study area were traversed, and farmers, residents and passers-by were asked if they knew anyone who kept honeybees or where honeybees were kept. Using this technique, it was possible to conduct complete surveys of all beekeepers and apiaries within a one-week period in each study area.

The data collected concerning each of the variables were analysed to establish whether significant variations in beekeeping conditions and management practices exist between African and non-African regions. The chi-square test was employed for the analysis of variables measured on a nominal scale, and the analysis of variables measured on an interval scale was accomplished using a difference of means $t$ test. For the purposes of this study, the chi-square statistic and the $F$-ratio are considered significant if the probability of error $<0.05$. It is important to note that the chisquare tests reported in this paper have been conducted using the actual counts or 
frequencies, but to facilitate comparisons for the reader percentages have been reported in the tables. The specific variables evaluated are discussed at the beginning of each section.

\section{Regional variation in beekeeping}

\section{Management practice}

Management practice examines variables which reflect both the impact of the hybrid and beekeepers' ability to respond to it, through the use of additional protective equipment, for example. Variables reflecting this are the ownership and use of a smoker or another smoking device to pacify bees and of a mask and gloves to protect the beekeeper from stings while the hive is being worked. Other management variables reflecting a beekeeper's ability to adapt successfully to the hybrid are hive type (fixed versus movable frame), use of supers, reproduction technique, and extraction method.

Beekeepers in the African region are better equipped with smokers than their colleagues in the uninfested region (Table 1). Every beekeeper interviewed in the African region either uses a smoker or some other smoking device, but only 80 per cent in the non-African region do so. Statistically, the variation in this practice between the two regions is highly significant $(\mathrm{p}<0 \cdot 01)$, suggesting that bees in the African region are probably more aggressive. The fact that nearly 20 per cent of the respondents in the areas free of the hybrid do not use smokers is surprising, since some smoking of even the most docile race of honeybees is recommended by apiculturalists. No differences were observed in the size of the smokers used in each region, and no jumbo smokers, reportedly common in Brazil and Bolivia, were seen.

The ownership and use of other protective equipment, masks and gloves, presents a slightly different picture. Mask ownership and use are more prevalent in the African area than in the area free of the hybrid, about 95 per cent and 85 per cent for both ownership and use in each area respectively (Table 1). Considerably fewer beekeepers own gloves than masks, and nearly equal proportions of beekeepers in each region own them, 55 per cent in the African area and 57 per cent in hybrid-free area. Glove use is even less common, and unexpectedly their use is more frequent in areas unaffected by the hybrid than in those areas where the hybrid is found, 48 and 41 per cent respectively (Table 1). In no case, however, are the variations between the two regions significant statistically. What does appear curious is that so many beekeepers in both regions do not wear masks when working with bees. As with smokers, the use of a mask, even with docile bees, is highly recommended.

Distinct practices are evident in hive type, use of supers, reproductive techniques, and extraction methods between the African and the non-African regions. About half the beekeepers use standard movable-frame hives (modern technology) in the African region, but only a quarter do so in the area free of the hybrid (Table 2). Similar trends are evident in the use of supers, additional hive boxes placed on top of the broad chamber to give the bees more space to store honey. In this case, 65 per cent use them in the African region compared with 38 per cent in the non-African region. More sophistication is also evident in techniques employed for colony reproduction. In the African region, 65 per cent use hive division, an efficient reproductive technique, whereas only 35 per cent utilize this technique in the non-African region. Finally, honey extraction using modern equipment, a centrifuge, is almost twice as common in the African region as it is in the region free of the hybrid- 45 and 26 per cent respectively (Table 2 ). In all four instances, the variables demonstrate statis- 
Table 1. Ownership and use of protective equipment

\begin{tabular}{|c|c|c|c|}
\hline Equipment and use & $\begin{array}{l}\text { African } \\
\text { region } \\
(\%)\end{array}$ & $\begin{array}{l}\text { Non-African } \\
\text { region } \\
(\%)\end{array}$ & $\begin{array}{c}\text { Total } \\
\text { ownership } \\
(\%)\end{array}$ \\
\hline \multicolumn{4}{|l|}{ Smoker ${ }^{a}$} \\
\hline Yes & $73 \cdot 2$ & $56 \cdot 6$ & $65 \cdot 1$ \\
\hline Other device & $26 \cdot 8$ & $24 \cdot 5$ & $25 \cdot 7$ \\
\hline Nothing & 0.0 & $18 \cdot 9$ & $9 \cdot 2$ \\
\hline Total & $\begin{array}{c}100 \cdot 0 \\
(n=56)\end{array}$ & $\begin{array}{c}100 \cdot 0 \\
(n-53)\end{array}$ & $\begin{array}{c}100 \cdot 0 \\
(n-109)\end{array}$ \\
\hline \multicolumn{4}{|l|}{ Mask ownership $b$} \\
\hline Yes & $94 \cdot 7$ & $85 \cdot 2$ & $90 \cdot 1$ \\
\hline No & $5 \cdot 3$ & $14 \cdot 8$ & $9 \cdot 9$ \\
\hline Total & $\begin{array}{c}100 \cdot 0 \\
(n=57)\end{array}$ & $\begin{array}{c}100 \cdot 0 \\
(n=54)\end{array}$ & $\begin{array}{c}100 \cdot 0 \\
(n=111)\end{array}$ \\
\hline \multicolumn{4}{|l|}{ Mask use $e^{c}$} \\
\hline Yes & $92 \cdot 8$ & $84 \cdot 3$ & $88 \cdot 8$ \\
\hline No & $5 \cdot 4$ & $15 \cdot 7$ & $10 \cdot 3$ \\
\hline Sometimes & $1 \cdot 8$ & 0.0 & $0 \cdot 9$ \\
\hline Total & $\begin{array}{c}100 \cdot 0 \\
(n=56)\end{array}$ & $\begin{array}{c}100 \cdot 0 \\
(n=51)\end{array}$ & $\begin{array}{c}100 \cdot 0 \\
(n=107)\end{array}$ \\
\hline \multicolumn{4}{|l|}{ Glove ownership $^{d}$} \\
\hline Yes & $54 \cdot 5$ & $56 \cdot 6$ & $56 \cdot 6$ \\
\hline No & $45 \cdot 5$ & $43 \cdot 4$ & $44 \cdot 4$ \\
\hline Total & $\begin{array}{c}100 \cdot 0 \\
(n=55)\end{array}$ & $\begin{array}{c}100 \cdot 0 \\
(n=53)\end{array}$ & $\begin{array}{c}100 \cdot 0 \\
(n=108)\end{array}$ \\
\hline \multicolumn{4}{|l|}{ Glove use $e^{c}$} \\
\hline Yes & $40 \cdot 8$ & $48 \cdot 1$ & $44 \cdot 3$ \\
\hline No & $48 \cdot 1$ & $50 \cdot 0$ & $49 \cdot 1$ \\
\hline Sometimes & $11 \cdot 1$ & $1 \cdot 9$ & $6 \cdot 6$ \\
\hline Total & $\begin{array}{c}100 \cdot 0 \\
(n=54)\end{array}$ & $\begin{array}{c}100 \cdot 0 \\
(n=52)\end{array}$ & $\begin{array}{c}100 \cdot 0 \\
(n=106)\end{array}$ \\
\hline
\end{tabular}

a chi-square $=11 \cdot 77$; highly significant; $p=0.01$

$b$ chi-square $=1 \cdot 86$; not significant; $p=0 \cdot 17$

$c$ chi-square $=3 \cdot 90 ;$ not significant; $p=0 \cdot 14$

${ }^{d}$ chi-square $=0.00 ;$ not significant; $p=0.98$

${ }^{e}$ chi-square $=3 \cdot 73$; not significant; $p=0 \cdot 16$

tically significant variation between the two regions. This tends to indicate that beekeepers in the African region are better equipped and more progressive in their management practices than their colleagues in the non-African region. These characteristics also suggest that those in the African regions are better able to adapt to the hybrid and exploit it effectively. Standard movable-frame hives and the use of supers allow the beekeeper more control over the colony and facilitate the requeening of aggressive colonies, the prevention of swarming and absconding, and better honey yields. The use of centrifuge extractors and colony reproduction using hive division, common in the African region, are also instrumental in increasing honey yields. 
Table 2. Management practices

\begin{tabular}{|c|c|c|c|}
\hline Management practice & $\begin{array}{c}\text { African } \\
\text { region } \\
(\%)\end{array}$ & $\begin{array}{l}\text { Non-African } \\
\text { region } \\
(\%)\end{array}$ & $\begin{array}{l}\text { Total } \\
(\% 0)\end{array}$ \\
\hline \multicolumn{4}{|l|}{ Hive type ${ }^{a}$} \\
\hline Standard & $47 \cdot 4$ & $24 \cdot 5$ & $36 \cdot 4$ \\
\hline Non-standard & $10 \cdot 5$ & $35 \cdot 9$ & $22 \cdot 7$ \\
\hline Fixed comb & $26 \cdot 3$ & $26 \cdot 4$ & $26 \cdot 4$ \\
\hline Mixed, standard and non-standard & $15 \cdot 8$ & $13 \cdot 2$ & $14 \cdot 5$ \\
\hline Total & $\begin{array}{c}100 \cdot 0 \\
(n=57)\end{array}$ & $\begin{array}{c}100 \cdot 0 \\
(n=53)\end{array}$ & $\begin{array}{c}100 \cdot 0 \\
(n=110)\end{array}$ \\
\hline \multicolumn{4}{|l|}{ Use of supers ${ }^{b}$} \\
\hline Yes & $65 \cdot 8$ & $38 \cdot 1$ & $51 \cdot 2$ \\
\hline No & $34 \cdot 2$ & $61 \cdot 9$ & $48 \cdot 8$ \\
\hline Total & $\begin{array}{c}100 \cdot 0 \\
(n=38)\end{array}$ & $\begin{array}{c}100 \cdot 0 \\
(n=42)\end{array}$ & $\begin{array}{c}100 \cdot 0 \\
(n=80)\end{array}$ \\
\hline \multicolumn{4}{|l|}{ Reproductive technique ${ }^{\circ}$} \\
\hline Hive division & $64 \cdot 8$ & $34 \cdot 7$ & $50 \cdot 5$ \\
\hline Swarm capture & $24 \cdot 1$ & $42 \cdot 9$ & $33 \cdot 0$ \\
\hline Mixture of both & $11 \cdot 1$ & $22 \cdot 4$ & $16 \cdot 5$ \\
\hline Total & $\begin{array}{c}100 \cdot 0 \\
(n=54)\end{array}$ & $\begin{array}{c}100 \cdot 0 \\
(n=49)\end{array}$ & $\begin{array}{c}100 \cdot 0 \\
(n=108)\end{array}$ \\
\hline \multicolumn{4}{|l|}{ Extraction technique $^{d}$} \\
\hline Centrifuge extraction & $45 \cdot 5$ & $25 \cdot 9$ & $35 \cdot 8$ \\
\hline Comb cutting & $50 \cdot 9$ & $74 \cdot 1$ & $62 \cdot 4$ \\
\hline Other & $3 \cdot 6$ & $0 \cdot 0$ & $0 \cdot 0$ \\
\hline Total & $\begin{array}{c}100 \cdot 0 \\
(n=55)\end{array}$ & $\begin{array}{c}100 \cdot 0 \\
(n=54)\end{array}$ & $\begin{array}{c}100 \cdot 0 \\
(n=109)\end{array}$ \\
\hline
\end{tabular}

${ }^{a}$ chi-square $=11 \cdot 81 ;$ highly significant; $p=0 \cdot 01$

${ }^{b}$ chi-square $=5 \cdot 07$; highly significant; $p=0 \cdot 02$

${ }^{c}$ chj-square $=9 \cdot 36$; highly significant; $p=0 \cdot 01$

$d$ chi-square $=7 \cdot 21$; highly significant; $p=0 \cdot 03$

\section{Honey production and colony numbers}

Average annual honey yields and the number of hives owned per beekeeper are examined as indicators of the hybrid's impact. However, it is important to note that honey production, and to some degree the number of hives a beekeeper owns, are also strongly affected by a number of other factors having little or nothing to do with the presence or absence of the African honeybee. These factors include management practices, agricultural conditions, competition from other apiaries, local flora, and climatic conditions. In a study of this character it is impossible to control completely for all these complications. Consequently, it is difficult to draw definite conclusions about variations in honey production. The primary problems in this study are the variety of hive types used, which directly affect honey production, their differing concentrations in each region, and the comparatively small size of the sample.

Regardless of the basis upon which honey production between the two regions is compared, average colony production is consistently greater in the African region. 
An initial comparison between the two regions, using reported colony production for all hive types, by all beekeepers $(n=72)$ reveals an average production of $30 \cdot 5 \mathrm{~kg}$ and $16.8 \mathrm{~kg}$ in the African and non-African regions respectively $(t=2 \cdot 85, p=0 \cdot 006)$. Even when efforts are made to control for production differences between different hive types, consistent differences persist. Using all types of movable-frame hives as the basis of comparison $(n=52)$, production averages $34.5 \mathrm{~kg}$ and $21 \cdot 4 \mathrm{~kg}$ in the African and non-African regions respectively $(t=2 \cdot 28, p=0 \cdot 027)$. Focusing only on production estimates for standard movable-frame hives $(n=28)$ similar differences appear, with production averaging $37.5 \mathrm{~kg}$ and $26.1 \mathrm{~kg}$ in the African and nonAfrican regions respectively $(t=1 \cdot 36, p=0 \cdot 187)$. These production differences are statistically significant in all but the last case.

The average number of colonies owned by beekeepers in each region varies considerably, from 46 in the African region to 14 in the non-African region. Statistically, however, these differences are not significant $(t=1 \cdot 71, p=0 \cdot 092)$.

\section{Apiary characteristics}

Apiary characteristics can reflect both the impact of the hybrid as well as beekeepers' ability or need to respond to it. Apiary location, frequency of stinging incidents and apiary tenure are assessed in this section. The distance apiaries are located from human dwellings reflects, to some degree, the problems or the perception of possible problems beekeepers or neighbours expect the bees to cause. The actual occurrence of stinging attacks on livestock and neighbours, should reveal whether bees in the areas infested with the African hybrid are more aggressive and whether they cause more problems for beekeepers. Apiary tenure affects the permanence of apiary locations and can cause beckeepers to rclocate their hives in response to complaints about aggressive bees. Beekeepers who rent or borrow their apiary sites are more vulnerable to displacement if their bees are troublesome to landowners or their neighbours.

Apiaries in both African and non-African regions are consistently located near human dwellings. Understandably, this makes management easier and reduces the possibility of theft or vandalism. Many apiaries in Peru are located adjacent to the beekeeper's house in a patio or garden. Overall, about half the apiaries in Peru are situated within $10 \mathrm{~m}$ of a dwelling and an additional quarter are located between 11 and $20 \mathrm{~m}$. Modest differences are evident between apiary locations in the two regions. Apiaries in the African regions are situated on average $16 \mathrm{~m}$ from dwellings, while those in non-African regions are located on average about $13 \mathrm{~m}$ away. The differences between the two regions, however, are not statistically significant $(t=1 \cdot 36$, $p=0 \cdot 178$ ).

The tendency for apiaries to be located so close to homes and livestock appears partly to be the result of the limited number of problems and complaints beekeepers have with their bees. In fact, problems with bees stinging neigbours and/or livestock were reported in a total of only about 15 per cent of the apiaries visited (Table 3 ). Stinging incidents demonstrate some minor differences between the two regions, being slightly more common in the African areas. Problems with bees stinging neighbours are the least prevalent and exhibit the least variation, occurring in 15 per cent of the African apiaries and 11 per cent of the non-African apiaries (Table 3). The differences are not statistically significant. 'Ihis is not so, however, with respect to stinging incidents involving animals. These are more common in apiaries in the African region-about 24 per cent compared with only 7 per cent in the area free of the hybrid. The chi-square statistic, although small (4.02), is statistically significant. The greater frequency of stinging incidents in the African region supports the 
Table 3. Stinging incidents or problems with humans or livestock reported in apiaries

\begin{tabular}{lccc}
$\begin{array}{l}\text { Stinging problems } \\
\text { or incidents }\end{array}$ & $\begin{array}{c}\text { African } \\
\text { region } \\
(\%)\end{array}$ & $\begin{array}{c}\text { Non-African } \\
\text { region } \\
(\%)\end{array}$ & $\begin{array}{c}\text { Total } \\
(\%)\end{array}$ \\
\hline $\begin{array}{l}\text { With humans } \\
\quad\end{array}$ & $18 \cdot 6$ & $11 \cdot 1$ & $14 \cdot 4$ \\
$\quad$ Yes & $81 \cdot 4$ & $88 \cdot 9$ & $85 \cdot 6$ \\
$\quad$ No & $100 \cdot 0$ & $100 \cdot 0$ & $100 \cdot 0$ \\
$\quad$ Total & $(n=44)$ & $(n=54)$ & $(n=97)$ \\
& & & \\
With livestock & & & \\
Yes & $23 \cdot 8$ & $7 \cdot 3$ & $14 \cdot 4$ \\
$\quad$ No & $76 \cdot 2$ & $92 \cdot 7$ & $85 \cdot 6$ \\
$\quad$ Total & $100 \cdot 0$ & $100 \cdot 0$ & $100 \cdot 0$ \\
& $(n=42)$ & $(n=55)$ & $(n=97)$ \\
\hline
\end{tabular}

$a^{a}$ chi-square $=0.57 ;$ not significant $; p=0.45$

${ }^{b}$ chi-square $=4 \cdot 02 ;$ moderately significant $; p=0.05$

impression that the hybrid bees are more aggressive. The fact that stinging incidents involving humans are minor and not statistically significant probably indicates that the public in the African region is aware of the bee's aggressiveness and consequently avoids the area around apiaries. Livestock, on the other hand, can make no such conscious efforts.

Apiary sites are located predominantly on land owned by the beekeeper, his family, or property to which they have unsufruct rights. About 90 per cent of all apiary sites are owned by the beekeeper and 10 per cent are borrowed from friends or relatives in both regions. In less than 1 per cent of all cases do beekeepers have formal financial agreements with property owners. This is slightly misleading, since even beekeepers who borrow sites from friends or relatives are expected to give a small portion of their crop $(10-20 \mathrm{~kg})$ to the owner in consideration for the use of the site. Differences are evident in apiary site tenure between the two regions, yet it is interesting to note that the frequency of borrowed, rented or leased sites in the African region is greater-12 per cent-than in the region free of the hybrid-about 7 per cent. If the aggressiveness of the hybrid bee is a problem, one might expect the situation to be reversed, reflecting increased difficulties in getting and keeping apiary sites with the troublesome bees. Nevertheless, statistically the differences are not significant (chi-square $=1 \cdot 46$ with 2 degrees of freedom, $p=0 \cdot 48$ ).

\section{Economic status}

Two variables are examined in this section-economic status and beekeepers' future plans. The economic status of the beekeepers can indicate both the impact of the African hybrid and the beekccpers' ability to respond to it. Many observers feel the hybrid drives hobbyists and part-timers out of beekeeping, favouring commercial operators because they can adapt to the hybrid bees more readily. The proportion of beekecpers in each group may thcrefore reflect the impact of the bec on beekeepers in the African region, as well as the ability of beekeepers in the non-African areas to 
Table 4. Economic status of beekeepers

\begin{tabular}{lccc}
\hline Economic status & $\begin{array}{c}\text { African } \\
(\%)\end{array}$ & $\begin{array}{c}\text { Non-African } \\
(\%)\end{array}$ & \multicolumn{1}{c}{$\begin{array}{c}\text { Total } \\
(\%)\end{array}$} \\
\hline Hobby & $47 \cdot 3$ & $93 \cdot 9$ & $69 \cdot 3$ \\
Business & $47 \cdot 3$ & $4 \cdot 3$ & $26 \cdot 9$ \\
Business and hobby & $3 \cdot 6$ & $0 \cdot 0$ & $1 \cdot 9$ \\
Institutional & $1 \cdot 8$ & $1 \cdot 8$ & $1 \cdot 9$ \\
Total & $100 \cdot 0$ & $100 \cdot 0$ & $100 \cdot 0$ \\
& $(n=55)$ & $(n=49)$ & $(n=104)$ \\
\hline
\end{tabular}

chi-square $=26 \cdot 54 ;$ highly significant; $p=0 \cdot 01$

adapt successfully to the bee in the future. Beekeepers' plans for future expansion or reduction of their apiaries reveal something of their perceptions of the possibilities for successful and expanded operations in the face of the possible problems presented by the African hybrid.

Beekeeping is primarily a hobby for most Peruvian beekeepers, as it seems to be in other Latin American countries, the US and Canada. Nearly three-quarters of all beekeepers consider themselves hobbyists, and only about a quarter report beekeeping as an economic activity. In this latter group over three-quarters reported that less than 25 per cent of their income was from beekeeping. A few individuals categorize their beekeeping as both a hobby and an economic activity and a small number of institutional owners exist (Table 4).

Sharp contrasts emerge in beekeepers' economic status between African and nonAfrican regions. In the area free of the hybrid, 94 per cent of the beekeepers are hobbyists, while in the African area hobbyists account for only 47 per cent of all beekeepers (Table 4). This difference is statistically highly significant. It is probable that hobbyists in that region have abandoned beekeeping in large numbers in response to the problems presented by the presence of the African hybrid. This would be consistent with experiences reported in Brazil after the arrival of the hybrid there (Cornejo 1971: 262; Gonçalves 1978: 479).

Peruvian beekeepers are optimists. Over three-quarters of those interviewed planned to increase the number of hives they owned in the coming year. Moderate numbers planned to maintain the same number of hives (15 per cent) or were uncertain about the future ( 7 per cent). Less than one per cent wanted to decrease the size of their holding. Plans for expanding or reducing the size of apiaries exhibit few differences between the two regions and these are not statistically significant (chisquare $=1 \cdot 56$ with 3 degrees of freedom, $p=0 \cdot 67$ ).

\section{Beekeeping experience and education}

Beekeeping experience and education help indicate the level of sophistication beekeepers bring to their task and their ability to solve their problems or identify those who can. The variables evaluated here focus primarily on practical experience, informal learning and formal educational activity related to beekeeping. These include the number of years of keeping bees, the number of other practitioners known to the beekeeper, coursework or training, and ownership of publications about beekeeping. 
Most Peruvian beekeepers have significant experience, three-quarters having worked with honeybees for four years or more. However, the length of experience varies between the two regions. Beekeepers in the African bee region have more experience, an average of 16 years, than their colleagues in the region free of the hybrid, 12 years. But the differences are not statistically significant $(t=1 \cdot 43$, $p=0 \cdot 155$ ). However, if the data are grouped into ranks, an interesting contrast appears. Thirty-two per cent of the beekeepers in the African bee region are recent entrants to beekeeping (1-3 years), but only 22 per cent in the region free of the hybrid. This is noteworthy because it is hardly a trend which would be expected, given the aggressive characteristics of the bee. Beekeepers in the African region seem more committed to beekeeping and nearly 20 per cent have kept bees for over 31 years; this contrasts with less than 2 per cent in the region free of the hybrid. It may be that superior ecological conditions for beekeeping in the African region and the potential for excellent yields encourage beekeepers to continue to keep bees despite the management problems presented by the hybrid bee.

Contact with other beekeepers represents a useful informal mechanism for beekeepers to learn from each other's experience, to obtain equipment, or to share its use. At the national level, over 85 per cent of all beekeepers have knowledge or contact with at least one other practitioner, but there are notable regional variations. Beekeepers from African bee areas are acquainted with more fellow practitioners than respondents in uninfested areas, an average of 1.8 and $1 \cdot 2$ respectively. These differences are highly significant statistically, indicating that a better network for sharing experience and knowledge exists among beekeepers in the African bee region $(t=2 \cdot 40, p=0 \cdot 017)$. This has undoubtedly helped them a great deal with the hybrid bee, but probably grew out of an earlier commercialization of beekeeping in this region rather than from the hybrid's presence.

Books, pamphlets, manuals and other printed materials about apiculture represent an auxiliary source of information for the improvement of knowledge and management skills. At the national level, slightly more than half of all beekeepers have access to such materials, but this varies somewhat regionally. Beekeepers from the African bee region are more likely to own books, manuals or pamphlets on beekeeping than their counter parts in the area free of the hybrid, 67 per cent against 53 per cent respectively. They are also likely to own more publications per person $(2 \cdot 5$ to $2 \cdot 1)$ but the differences are not significant statistically $(t=0 \cdot 29, p=0 \cdot 772)$. Again, it appears that practitioners in the African bee areas are better informed about beekeeping and thus in a better position to accommodate themselves to the negative attributes of the hybrid bee.

Few of those interviewed ( 15 per cent) had any kind of formal course or training in beekeeping, but about half of this group received general university training. The remainder is divided between those trained in high school, by extension personnel, or through correspondence courses. Some form of training is more common among those who work with the African bees than those who do not, 24 per cent and 10 per cent respectively. However, this does appear to be consistent with the pattern of other variables; beekeepers in the African bee region are characteristically more knowledgeable and better trained than their colleagues in areas free of the hybrid, though the differences between the groups are not statistically significant (chi-square $=2 \cdot 4$ with 1 degree of freedom, $p=0 \cdot 12$ ).

\section{Beekeepers' problems}

Numerous problems beset Peruvian beekeepers, over 90 per cent of all respondents 
identifying one or more as being significant. Primary problems are those cited by more than 10 per cent of all the respondents. These, in order of importance, are the lack of technical assistance, unfavourable weather, insecticide use, poor honey flora, and inadequate sources of beekeeping supplies and equipment (Table 5). Secondary problems, reported by fewer than 10 per cent of the respondents, are pests and parasites, lack of credit, African bees, overcrowding of apiaries, disease, and aggressiveness. A myriad of other specialized and idiosyncratic problems are cited by slightly over a third of the beekeepers.

The number of beekeepers with problems and the number of problems they experience vary little between the African and non-African regions. Unexpectedly, slightly fewer individuals in the African bee region report problems than those in areas free of the hybrid, 79 and 84 per cent respectively. However, they do cite more problems per capita than their colleagues, an average of 1.8 compared to 1.4 (Table 5).

Differences are evident in the kinds of problems experienced by beekeepers in the two regions. Beekeepers in the region free of the African bee have considerably more complaints about lack of technical assistance, the excessive use of insecticides, and poor honey flora, but roughly the same number in each region have trouble with bad weather and inadequate sources of beekeeping supplies. On the other hand, beekeepers in the African bee region voice more dissatisfaction with regard to secondary problems. Between 10 and 15 per cent have complaints about the lack of credit, the African bee, and overcrowding of apiaries. None of their counterparts in unaffected

Table 5. Beekeepers' most frequently reported problems ${ }^{a}$

\begin{tabular}{lccc}
\hline Problems & $\begin{array}{c}\text { African } \\
\text { bee region }\end{array}$ & $\begin{array}{c}\text { Non-African } \\
\text { bee region }\end{array}$ & Total \\
\hline Percentage reporting problems & $\begin{array}{r}78 \cdot 9 \\
(n=57)\end{array}$ & $\begin{array}{c}83 \cdot 6 \\
(n=55)\end{array}$ & $\begin{array}{c}81 \cdot 3 \\
(n=112)\end{array}$ \\
$\begin{array}{l}\text { Average number of problems reported per } \\
\text { beekeeper }\end{array}$ & $1 \cdot 8$ & $1 \cdot 4$ & $1 \cdot 6$ \\
Number of problems cited & 80 & 66 & 146 \\
Primary problems & & & \\
Lack of technical assistance & $24 \cdot 4$ & $32 \cdot 6$ & $28 \cdot 6$ \\
Weather & $20 \cdot 0$ & $17 \cdot 4$ & $18 \cdot 7$ \\
Insecticide use & $8 \cdot 9$ & $21 \cdot 7$ & $15 \cdot 4$ \\
Poor honey flora & $6 \cdot 7$ & $19 \cdot 6$ & $13 \cdot 2$ \\
Inadequate supplies including & & & $11 \cdot 0$ \\
$\quad$ wax foundation & $13 \cdot 3$ & $8 \cdot 7$ & \\
Secondary problems & & & $9 \cdot 9$ \\
Pests and/or parasites & $8 \cdot 9$ & $10 \cdot 9$ & $7 \cdot 7$ \\
Lack of credit & $15 \cdot 6$ & $0 \cdot 0$ & $7 \cdot 7$ \\
Africanized bees & $15 \cdot 6$ & $0 \cdot 0$ & $7 \cdot 7$ \\
Overcrowding of apiaries & $8 \cdot 9$ & $0 \cdot 0$ & $3 \cdot 3$ \\
Disease & $4 \cdot 4$ & $2 \cdot 2$ & $3 \cdot 3$ \\
Aggressiveness & $4 \cdot 4$ & $2 \cdot 2$ & $37 \cdot 4$ \\
Other problems & $46 \cdot 4$ & $26 \cdot 1$ & \\
\hline
\end{tabular}

a Percentages and totals in the table are calculated on the number of respondents in each category. Since multiple responses are possible, column totals are more than 100 per cent 
areas cited any of these problems. Differences reported in the other subcategories are generally inconsequential.

The differences in the problems beekeepers recognize in the two regions seem to reflect variations in the environment, local agricultural conditions and the commercial status of beekeeping. In the areas free of the African hybrid, where largescale commercial agriculture is more common and natural vegetation sparse, beekeepers cite problems with insecticides and poor honey flora. Beekeepers in that region also have less technical expertise and hence frequently cite their need for technical assistance. In the African bee region, which is more advanced in an apicultural sense, beekeepers feel inadequate credit and the overcrowding of apiaries, as well as the presence of the hybrid bee, to be their principal problems.

\section{Changes in bee behaviour}

About 40 per cent of all beekeepers interviewed in the study felt some behavioural changes had taken place in their colonies during the last two to three years. Aggressiveness, swarming and other miscellaneous changes were the most frequently reported. By a margin of almost 2 to 1 more individuals noted such changes in the African bee region than in the region free of the hybrid (Table 6). Increased aggressiveness was cited by over 85 per cent of the respondents in the African bee areas, but only by 44 per cent in the uninfested areas. Increased swarming was experienced by about a quarter in both regions. Fully half of those from the hybridfree region noted other miscellaneous behavioural changes, whereas only 11 per cent responded similarly in the African bee regions (Table 6). Both increased and decreased honey production were cited by small percentages of the respondents in each region, and less aggressiveness and quicker flight activity were cited by similar numbers only in the African bee areas. The increased perception of aggressiveness by beekeepers in the African bee areas is consistent with the bee's vigorous nest defence. The fact that the same percentage in both regions noted increased swarming is rather puzzling, since the hybrid purportedly swarms excessively.

Table 6. Changes in honeybee behaviour ${ }^{a}$

\begin{tabular}{lccc}
\hline Behaviour change & $\begin{array}{c}\text { African } \\
\text { region } \\
(\%)\end{array}$ & $\begin{array}{c}\text { Non-African } \\
\text { region } \\
(\%)\end{array}$ & $\begin{array}{c}\text { Total } \\
(\%)\end{array}$ \\
\hline Reporting change & $\begin{array}{c}49 \cdot 1 \\
(n=57)\end{array}$ & $\begin{array}{c}29 \cdot 1 \\
(n=55)\end{array}$ & $\begin{array}{c}39 \cdot 3 \\
(n=112)\end{array}$ \\
More aggressive & $85 \cdot 7$ & $43 \cdot 8$ & $70 \cdot 5$ \\
More swarming & $25 \cdot 0$ & $25 \cdot 0$ & $25 \cdot 0$ \\
More productive & $3 \cdot 6$ & $12 \cdot 5$ & $6 \cdot 8$ \\
Less productive & $7 \cdot 2$ & $6 \cdot 3$ & $6 \cdot 8$ \\
Less aggressive & $3 \cdot 6$ & $0 \cdot 0$ & $2 \cdot 3$ \\
Fly faster & $3 \cdot 6$ & $0 \cdot 0$ & $2 \cdot 3$ \\
Other & $10 \cdot 7$ & $50 \cdot 0$ & $25 \cdot 0$
\end{tabular}

a Percentages and totals in the table are calculated on the number of respondents in each category. Since multiple responses are possible, column totals are more than 100 per cent 


\section{Management adjustments}

Most respondents in the African bee region had heard of the presence of the African or ' $k$ iller' bees in Peru. Yet only about half had noticed changes in their bees' behaviour, and surprisingly only a quarter acknowledged the presence of the African hybrid in their apiaries. Many individuals thought the more aggressive behaviour of their bees had been caused by their lack of attention to their colonies. That is, they believed the bees did not recognize them or were no longer used to humans, and that by working the colonies more regularly their aggressiveness would diminish, a belief having no scientific basis.

Those who acknowledged the hybrid's presence in their apiaries had made some adjustments in their management practices, the number of changes averaging more than two and including a variety of responses (Table 7). Most popular were the use of protective clothing and the requeening of aggressive colonies. These were closely followed by the use of more smoke and the destruction of aggressive colonies and swarms by burning them out. Less-frequent changes included the use of gloves, changing apiary locations, making less noise, and working bees at special times of the day. It is indicative of the hybrid that all these management adjustments relate to its aggressiveness and are similar to those made in Brazil. A surprising fact is that requeening, a technically advanced and expensive practice, is so widely employed. Also notable is the limited number of beekeepers in Peru who relocate their apiaries as a result of the hybrid's presence.

Respondents also reported (multiple responses per individual) on the advantages and disadvantages of working with the hybrid bee. There was almost complete agreement concerning the advantages: they work harder and produce more $(66 \cdot 7$ per cent in both cases). Some suggest that they are also more resistant to disease and pest problems ( 20 per cent). The hybrid's greatest single disadvantage, according to the respondents, is its aggressiveness, cited as a problem by nearly 80 per cent. Swarming follows as a distant second $(20$ per cent), with the production of excessive propolis (13.3 per cent), lower honey production ( $13 \cdot 3$ per cent), and problems with neighbours $(6 \cdot 7$ per cent $)$ following, as secondary problems.

Table 7. Management changes reported by beekeepers in response to the African hybrid ${ }^{a}$

\begin{tabular}{lcc}
\hline Management changes & $\begin{array}{c}\text { Percentage } \\
\text { reporting }\end{array}$ & $\begin{array}{c}\text { Number } \\
\text { reporting } \\
\text { change }\end{array}$ \\
\hline Use more clothes & $35 \cdot 7$ & 5 \\
Requeening & $35 \cdot 7$ & 5 \\
Use more smoke & $28 \cdot 6$ & 4 \\
Burn out aggressive colonies & $28 \cdot 6$ & 4 \\
Wear gloves & $21 \cdot 4$ & 3 \\
Change apiary locations & $21 \cdot 4$ & 3 \\
Other & $21 \cdot 4$ & 3 \\
Make less noise & $14 \cdot 3$ & 2 \\
Work bees at specific times & $7 \cdot 1$ & 1 \\
\hline
\end{tabular}

\footnotetext{
a Percentages and totals in the table are calculated on the number of respondents in each category. Since multiple responses are possible, column totals are more than 100 per cent
} 


\section{Conclusions}

Beekeeping practice and management techniques in Peru demonstrate consistent differences between the region affected by the African honeybee and the region free of the hybrid. Beekeeping practice in the African region is characterized by the more frequent ownership and use of modern equipment-smokers, masks, gloves, standard movable-frame hives, hive supers, and centrifuge extractors - whereas beekeepers in the region free of the hybrid typically use less-sophisticated and lessefficient equipment. Management techniques and goals also demonstrate more sophistication among those beekeepers in the region affected by the African hybrid. Typically, they have had more experience in keeping bees, their per capita honey yields are greater, they are better informed about modern beekeeping practices, they have more contacts with other beekeepers and they are more commercially orientated than their colleagues in the region free of the hybrid honeybee.

Surprisingly, only about half the beekeepers in the African region reported noticing any change in the behaviour of their bees over the five-year period before the interviews - the same time period during which many of these beekeeper's apiaries became infested with the African honeybee. Of these beekeepers, the vast majority did report increased aggressiveness as the most significant change, a finding consistent with experience in other countries affected by the hybrid. Although this study demonstrated that stinging incidents involving humans and livestock are slightly more common in the African region, statistically these differences are not significant.

Beekeepers report making a number of management changes in order to adapt to the greater aggressiveness demonstrated by the African hybrid, including using more smoke, wearing more protective clothing, requeening, and moving apiaries to more remote locations. Some of these changes are confirmed in the comparative analysis of management practices between the two regions, yet others are not. The siting of apiaries is a case in point. In the region free of the hybrid, apiaries are located about $13 \mathrm{~m}$ from human dwellings, whereas in the African bee region they are located $16 \mathrm{~m}$ away but this difference is not statistically significant.

Beekeepers' responses to questions concerning their problems suggest that the African bee, while bothersome, is not a major problem. Among beekeepers in the African region, lack of technical assistance and poor weather rank ahead of the African bee as their most significant problems. The picture that emerges from this analysis of the African honeybee in Peru shows that beekeepers do not view the hybrid as a major problem. Many beekeepers did not report even noticing any changes in their colonies' behaviour as they became infested over the last five years. Furthermore, apiaries in the African region are located fairly close to human dwellings and animal pens, just as they are in the region free of the hybrid. This does not conform with the hybrid's reputation as unduly aggressive nor with expert advice to beekeepers to locate hives of African bees far from humans and animals. In Venezuela and in other countries, for example, beekeepers have been advised to locate colonies $200-300 \mathrm{~m}$ from people or livestock (Moffett and Maki 1988). Management practices and equipment in the African bee region are considerably more sophisticated and advanced than those in the region free of the hybrid, in almost all cases providing beekeepers with the capability of dealing successfully with the negative characteristics of the hybrid bee.

The question arises as to the extent that this increased sophistication represents a response to the hybrid's negative characteristics, the earlier development of technical and managerial sophistication in the region now occupied by the African hybrid, or 
the abandonment of beekeeping by part-time and hobby beekeepers who are typically less sophisticated in their equipment and management techniques. Lack of historical data on beekeeping in Peru makes this question difficult to answer. It is possible that the greater technical and managerial sophistication in the African area, or at least parts of it, are the result of settlement by Italian and German colonists during the late nineteenth and early twentieth centuries. These colonists brought honeybees, beekeeping equipment and apicultural knowledge with them from Europe, and indeed some of the most successful commercial beekeepers today are their descendants. Another possible explanation is that the region occupied by the African hybrid had some of the best environmental conditions for beekeeping; consequently this has simply been the most attractive area for commercially orientated beekeepers. Finally, it is also possible that once the African hybrid arrived in that region, hobby beekeepers abandoned beekeeping in large numbers, leaving only the larger, commercially orientated beekeepers in operation. The technical and managerial sophistication exhibited in the region probably represents a combination of all of these factors (Kent 1986).

As beekeepcrs, the beekeeping industry, and the public in general prepare for the arrival of the African hybrid in Mexico and the southern US, experience with the African bee in Peru can provide some insight for policy-makers. The Peruvian case clearly demonstrates that although the African hybrid may be more problematic, for beekeepers with sound technical and managerial knowledge of beekeeping, the presence of the African hybrid is not as disruptive as often portrayed. It is probable that the more sophisticated beekeepers typical of Mexico and the US will be able to adapt to the arrival of the hybrid without serious problems. This conclusion is similar to that drawn by Camazine and Morse (1988), who suggest that in the US the negative impacts of the African hybrid when it arrives will be relatively minor. These conclusions are supported by Taylor (1985), who notes that managing the invasion of the African honeybee in the US is clearly possible. The most severe effects according to his analysis will probably be on the queen-rearing and package-bee industries concentrated in the southern states and on the practice of migratory beekeeping. It is important to note that in the Peruvian case, beekeepers in the region infested with the African hybrid adapted to the presence of the bee without any kind of governmental or private assistance. While this might not be the most desirable state of affairs, it seems that with limited extension assistance beekeepers could adapt to the arrival of the hybrid more easily. This suggests that instead of devoting scarce funds to the development of a barrier to block or retard the diffusion of the hybrid through the Isthmus of Tehuantepec (Tew et al. 1988), the US and Mexican governments should dedicate these funds to extension education for beekeepers to help them and the public prepare for the inevitable arrival of the hybrid in central and northern Mexico and the southern US.

\section{Acknowledgements}

Numerous Peruvian beekeepers took time from their labours and leisure to respond to the author's questionnaire and enquiries. Their help is most gratefully acknowledged. The Dellplain Program in Latin American Geography at Syracuse University, directed by Dr David $\mathbf{J}$. Robinson, assisted in providing logistical support for this research in several of the case study sites in Peru. The critical comments of two anonymous referees are acknowledged. 


\section{References}

Alata Condor, J. (1976) Las Abejas Africanas y/o Sus Hibridos y Su Posible Presencia en el Valle de Chanchamayo. Lima: Ministerio de Alimentación, Dirección General de Investigación, Informe Especial No. 3.

Caballero, A. (1981) Personal communication, 21 April, Lima, Peru.

Calkins, C. O. (1983) Research on exotic insects. In Exotic plant pests and North American agriculture (C. L. Wilson and C. L. Graham, eds), pp. 321-359. New York: Academic Press.

Camazine, S. and Morse, R. A. (1988) The Africanized honeybee. American Scientist 76(5), $465-471$.

Committee on the African Honeybee (1972) Final Report: Committee on the African Honeybee. Washington, D.C.: National Academy of Sciences.

Cornejo, L. G. (1971) Management technology of the African bee. American Bee Journal III (7), 262-263.

Crosby, A. W. (1986) Ecological imperialism: the biological expansion of Europe, 900-1900. Cambridge: Cambridge University Press.

Daly, H. U. (1981) Letter to the author, 8 March, Berkeley, California.

Dávila, M., Ortiz, M. S. and de Huiza, I. R. (1980) Presencia de la abeja africanizada en el Peru. Revista Peruana de Entomología 23(1), 125-127.

Elton, C. S. (1958) The ecology of invasions by plants and animals. London: Chapman and Hall.

Fierro, M. M., Munoz, M. J., Lopez, A., Sumuano, X., Salcedo H. and Roblero, G. (1988) Detection and control of the Africanized bee in coastal Chiapas, Mexico. American Bee Journal 128(4), 272-275.

Frey, E. (1982) Personal communication, 6 August, Oxapampa, Peru.

Gerardi, M. H. and Grimm, J. K. (1979) The history, biology, damage, and control of the gypsy moth Porthetria dispar $(L)$. Rutherford: Fairleigh Dickinson University Press.

Gonçalves, L. S. (1974) The introduction of the African bees (Apis mellifera adansonii) into Brazil and some comments on their spread in South America. American Bee Journal 114, $414-415,419$.

Gonçalves, L. S. (1978) Impacto causado po las abejas africanizadas en la América del Sur. Gaceta del Colmenar 40(460), 474-483.

Harper, J. D. (1982) Africanized bee has spread to Ecuador. Speedy Bee II(1), 7-8.

Horsfall, J. G. (1983) Impact of introduced pests on man. In Exotic plant pests and North American agriculture (C. L. Wilson and C. L. Graham, eds), pp. 1-13. New York: Academic Press.

Kaufman, M. (1981) Personal communication, 17 April, La Merced, Peru.

Kempff Mercado, N. (1973) The African bees: contribution to their knowledge. Apiacta 8(3), $121-126$.

Kent, R. B. (1986) Beekeeping regions, technical assistance, and development policy in Peru. Yearbook, Conference of Latin Americanist Geographers 12, 22-33.

Kent, R. B. (1988) The introduction and diffusion of the African honeybee in South America. Association of Pacific Coast Geographers Yearbook 50, 21-43.

Lattin, J. D. and Oman, P. (1983) Where are the exotic insect threats? In Exotic plant pests and North American agriculture (C. L. Wilson and C. L. Graham, eds), pp. 93-137. New York: Academic Press.

Lizarraga, E. (1981) Personal communication, 21 March, Lima, Peru.

McDowell, R. (1984) The Africanized bee in the United States: what will happen to the US beekeeping industry? Washington, D.C.: Government Printing Office, Agricultural Economic Report No. 519.

Michener, C. D. (1973) The Brazilian honeybee. Bio Science 23(9), 523-527.

Michener, C. D. (1975) The Brazilian bee problem. Annual Revue of Entomology 20, 399-416.

Moffett, J. O. and Maki, D. L. (1988) Venezuela and the Africanized bee. American Bee Journal 128(12), 827-830.

Moffett, J. O., Maki, D., Andre, T. and Flierro, M. M. (1987) The Africanized honeybee in 
Chiapas, Mexico. American Bee Journal 127(7), 517-519.

Mooney, H. A. and Drake, J. A. (1987) The ecology of biological invasions. Environment $29(5), 10-15,34-37$.

Murakami, J. (1982) Personal communication, 6 August, Oxapampa, Peru.

Nunamaker, R. A. (1979) Newspaper accounts of Africanized bees are designed to frighten pcople-being stung by the press. American Bee Journal 119(8), 587-588, 591-592, (9), 646-647, 657.

Ojeda, L. (1981) Personal communication, 21 April, Lima, Peru.

Pimental, D. (1986) Biological invasions of plants and animals in agriculture and forestry. In Ecology of biological invasions of North America and Hawaii (H. A. Mooney and J. A. Drake, eds), pp. 149-162. New York: Springer-Verlag.

Pizarro, V. (1982) Personal communication, 21 June, Huancayo, Peru.

Presada, W. A. (1981) Rebirth of Brazil's bee industry. American Bee Journal 121(9), 630.

Rinderer, T. E., Wright, J. E., Shimanuki, H., Parker, F., Erickson, E. and Wilson, W. T. (1987) The proposed honeybee regulated zone in Mexico. American Bee Journal 127(3), $160-164$.

Roughgarden, J. (1986) Predicting invasions and rates of spread. In Ecology of biological invasions of North America and Hawaii (H. A. Mooney and J. A. Drake, eds), pp. 179188. New York: Springer-Verlag.

Sailer, R. I. (1983) History of insect introductions. In Exotic plant pests and North American agriculture (C. L. Wilson and C. L. Graham, eds), pp. 15-38. New York: Academic Press.

Seeley, T. D. (1985) Honeybee ecology: a study of adaptation in social life. Princeton: Princeton University Press.

Sharpless, F. E. (1983) Spread of organisms with novel genotypes: thoughts from an ecological perspective. Recombinant DNA Technical Bulletin 6(2), 43-56.

Simberloff, D. (1986) Introduced insects: a biogeographic and systematic perspective. In Ecology of biological invasions of North America and Hawaii (H. A. Mooney and J. A. Drake, eds), pp. 1-26. New York: Springer-Verlag.

Sommer, P. G. (1979) Comportamento das abelhas africanizadas no Paraná diante das observaçoes feitas no periodo de 1960-1970. In Apiculture in hot climates (Apimondia, ed.). Bucharest: Apimondia.

Spivak, M. (1981) Letter to the author, 14 February, Lawrence, Kansas.

Stearman, A. M. (1981) Working the Africans in eastern Bolivia. American Bee Journal $121(1), 28-35,43-44$.

Stort, A. C. and Gonçalves, L. S. (1979) A abelha africanizada e a situaçao atual da apicultura no Brasil. Ciencia e Cultura 31(1), 32-43.

Taylor, O. R. (1977) The past and possible future spread of Africanized honeybees in the Americas. Bee World 58(1), 19-30.

Taylor, O. R. (1985) African bees: potential impact in the United States. Bulletin of the Entomological Society of America 31(4), 15-24.

Taylor, O. R. and Williamson, G. B. (1975) Current status of the Africanized honeybee in northern South America. American Bee Journal 115(3), 92-93, 98.

Tew, J. E., Bare, C. H. and Villa, J. D. (1988) The honeybee regulated zone in Mexico. American Bee Journal 128(10), 673-675.

Villa, J. D. (1987) Africanized and European colony conditions at different elevations in Colombia. American Bee Journal 127(1), 53-57.

Wiese, H. (1977) Apiculture with Africanized bees in Brazil. American Bee Journal 117(3), $166-168,170$.

Winston, M. L. (1987) The biology of the honeybee. Cambridge, Mass.: Harvard University Press. 